\title{
HUBUNGAN PENGGUNAAN KOMPUTER DAN GADGET TERHADAP PENURUNAN TAJAM PENGLIHATAN
}

\author{
Mayarani $^{1)}$, Risfa Nanda Aulia ${ }^{2)}$ \\ ${ }^{1}$ Dosen Program Studi Diploma Tiga Opthometri STIKes Dharma Husada Bandung \\ ${ }^{2}$ Mahasiswa Program Studi Diploma Tiga Opthometri STIKes Dharma Husada Bandung \\ nengmayarani@gmail.com \\ damaylayasmine@gmail.com
}

\begin{abstract}
Abstrak
Pengguna internet di Indonesia yang berasal dari kalangan anak-anak dan remaja mencapai 30 juta. Pada pengguna komputer, sebagian besar darinya menghabiskan waktu berjam-jam menatap layar komputer, tanpa mengistrahatkan mata. Dimana penggunaan komputer dalam waktu yang cukup lama tanpa istrahat menyebabkan kelelahan pada mata dan risiko terjadinya stres yang berulang pada ototototmata yang bisa berlanjut pada penurunan fungsi otot-otot mata sehingga berefek pada gangguan penglihatan/penurunan visus. Tujuan penelitian ini adalah untuk mengetahui hubungan penggunaan komputer dan gadget terhadap penurunan tajam penglihatan. Jenis data yang digunakan penulis dalam penelitian ini adalah data skunder yaitu data yang diperoleh dari jurnal, dan internet. Metode yang digunakan dalam penelitian ini adalah studi literatur, yaitu membandingkan 5 judul artikel nasional dari tahun 2013 sampai dengan tahun 2019. Hasil studi menunjukkan terdapat kesamaan bahwa ada hubungan antara penggunaan komputer dan Gadget dengan intensitas waktu yang lama dan jarak pendang yang dekat, akan mengakibatkan penurunan tajam penglihatan. Dengan demikian saran yang dapat dibentuk sebaiknya pengguna Gadget untuk tidak bermain gadget dalam intensitas waktu yang lama dan lakukan kiat 20-20-20, yaitu mengalihkan pandangan dari layar setiap 20 menit untuk menatap objek yang berjarak sekitar 20 kaki atau 6 meter selama 20 detik.Dengan jarak maksimal 30 $\mathrm{cm}$ ketika menatap layar gadget atau komputer. Menyesuaikan posisi layar, untuk mengurangi refleksi cahaya dan seringlah berkedip untuk melembabkan mata.
\end{abstract}

Kata Kunci : Tajam Penglihatan, Waktu, Jarak

\section{PENDAHULUAN}

Tajam penglihatan adalah kapasitas mengenal ruang atau gambar pada system penglihatan. Batas tajam penglihatan disebabkan oleh faktor optikal dan neural atau kombinasi keduanya. Batas optikal berhubungan dengan pola difraksi. Penurunan resolusi kualitas gambar direndahkan oleh kelainan fokus seperti myopia, hypermetropia, astigmat, atau kegagalan untuk memaksimalkan fokus oleh akomodasi dan kecembungan lensa. Batas neural disebabkan oleh kepadatan respon retina dan interaksi neural didalam retina (Benjamin, 1998) Jurnal Penelitian Kesehatan STIKes Dharma Husada Bandung
Faktor-faktor internal yang mempengaruhi tajam penglihatan terdiri dari anatomi retina, status refraksi, ukuran pupil, aberasi, faktor psikologis, ukuran benda yang dilihat, pencahayaan, kontras, warna dan lamanya melihat benda tersebut. Semakin besar huruf semakin mudah dibaca. Faktorfaktor eksternal yang mempengaruhi tajam penglihatan terdiri lingkungan, kebiasaan dan kebiasaan serta nutrisi (Giannakopoulou, 2008) Kemajuan ilmu pengetahuan dan teknologi mampu meningkatkan kemajuan hidup manusia. Perkembangan zaman saat ini, gaya hidup masyarakat lebih sering 
JURNAL SEHAT MASADA VOLUME XVI menggunakan media audiovisual yang modern yang lama. kemajuan komputer selain berdampak positif bagi manusia, dapat pula berdampak negatif pada pemakainya. Salah satu hal yang paling mudah diamati adalah dampak komuter bagi kesehatan individu pemakainya. Walaupun radiasi yang ditimbulkan oleh layar komputer sifatnya kecil. Yang perlu diperhatikan adalah intensitas, durasi dan frekuensi radiasi tersebut menyinari tubuh khususnya mata. Secara luas, memang dikenal sebagai gangguan kesehatan yang diakibatkan oleh pemakaian komputer, antara lai Revetitive Stress/Strain Injury (RSI), kelelahan mata dan sakit kepala merupakan keluhan yang paling banyak dikeluhkan para pemakai komputer. Computer vision syndrom (CVS) juga telah dikenal sebagai dampak negative dari pemakaian computer. CVS sendiri merupakan kelelahan mata yang dapat mengakibatkan sakit kepala, penglihatan ganda (diplopia),penglihatan silau, dan berbagai masalah lainnya (Dahlan, 2006). Saat ini komputer banyak digunakan sebagai alat bantu dalam sector pendidikan. Dalam masa pakai yang lama, radiasi yang ditimbulkan oleh layar monitor komputer dapat menyebabkan masalah kesehatan mata yaitu penurunan ktajaman penglihatan (Sartono, 1999)

Hasil penelitian mencatat pengguna internet di Indonesia yang berasal dari kalangan anak-anak dan remaja diprediks imencapai 30 juta. penggunaan komputer dalam waktu yang cukup lama tanpa istrahat menyebabkan kelelahan pada mata dan risiko seperti televisi dan komputer dalam waktu

NOMOR 1 Januari 2022

ISSN : 1979-2344

terjadinya stres yang berulang pada otot-otot mata yang bisa berlanjut pada penurunan fungsi otot-otot mata sehingga berefek pada gangguan penglihatan/penurunan visus.( Ningsing, 2015 )

Salah satu kemajuan teknologi yang banyak digunakan adalah gadget. Salah satu bentuk gadget adalah smartphone. Dampak negatif dari pengunaan gadget yaitu menurunnya fungsi penglihatan, akibat paparan sinar dari layar monitor (LED/LCD) dan penyinaran lainnya. Anak sekolah dengan kebiasaan bermain game online dalam durasi yang lama rentan mengalami gangguan pada tajam penglihatan. Durasi bermain game online tanpa jeda berisiko menyebabkan kelelahan mata yang kemudian dapat menurunkan nilai visus mata.

\section{METODOLOGI}

Sumber data yang digunakan pada literatur review ini yaitu artikel atau jurnal ilmiah yang telah terakreditasi. Pencarian literatur dilakukan dengan menggunakan Kata kunci 'penggunaan komputer dan gadget', 'sindrom mata', 'kelelahan mata', 'tajam penglihatan', 'penurunan tajam penglihatan dan gadget'. Sedangkan pencarian artikel atau jurnal berbahasa Inggris, kata kunci yang digunakan adalah 'computer use and gadget', 'eye syndrome', 'asthenopia', 'computer vision syndrome', 'comparison use computer to asthenopia', 'visual acutiy'.

Artikel atau jurnal ilmiah dilakukan pemilahan dengan menggunakan kriteria inklusi dan eksklusi. Kriteria inklusi adalah 
JURNAL SEHAT MASADA VOLUME XVI

karakteristik umum dari suatu target yang akan dijadikan subjek penelitian. Kriteria inklusi yang digunakan dalam penelitian ini adalah:

1. Artikel menggunakan Bahasa Indonesia atau Bahasa Inggris.

2. Isi artikel mengacu pada lingkup penelitian yaitu tentang hubungan penggunaan komputer dan gadget terhadap penurunan tajam penglihatan.

3. Artikel merupakan jurnal penelitian yang telah terakreditasi. Untuk mengetahui jurnal yang terakreditasi, penulis menggunakan jurnal yang sudah ber ISSN, atau jurnal yang sudah terdaftar di SINTA, DIKTI atau LIPI untuk jurnal nasional, dan SCImago Journal Rank untuk jurnal internasional.

4. Rentang waktu penerbitan jurnal berbahasa Indonesia maksimal 5 tahun terakhir (20162020), dan jurnal berbahasa Inggris maksimal 10 tahun terakhir (2011-2020).

Adapun kriteria eksklusi adalah mengeluarkan atau menghilangkan beberapa subjek yang memenuhi kriteria inklusi dari penelitian dikarenakan kriteria dan sebab-
NOMOR 1 Januari 2022

ISSN : 1979-2344

sebab tertentu. Kriteria eksklusi dalam penelitian ini adalah:

1. Artikel tidak dalam bentuk full teks (tidak dapat diakses penuh).

2. Artikel diterbitkan dibawah tahun 2011.

Literatur yang digunakan diambil dari berbagai database artikel atau jurnal ilmiah, seperti google scholar, Indonesia onesearch, PubMed, NCBI, aaojournal, $J A M A$, dan lainnya. pengumpulan referensi sumber rujukan, penulis menggunakan aplikasi mendeley.

Metode tinjauan literatur yang digunakan adalah metode naratif review, yaitu menggambarkan dan menilai artikel dengan mensintesis informasi ke dalam format yang mudah digunakan. Setelah membaca dan memahami setiap ide pokok dari literatur yang dipilih, kemudian penulis membuat matriks literatur untuk membantu dalam menganalisis dan mensintesis literatur.

\section{HASIL}

Tabel 1 Matriks Hasil Kajian Literatur

\begin{tabular}{|c|c|c|c|}
\hline No & $\begin{array}{c}\text { Nama, Judul, } \\
\text { Tahun Publikasi }\end{array}$ & Metode & Hasil \\
\hline 1 & $\begin{array}{l}\text { Nama Peneliti : } \\
\text { Maya Syulfahrita } \\
\text { Pertiwi } \\
\text { Judul : } \\
\text { Gambaran Perilaku } \\
\text { Penggunaan Gadget } \\
\text { Dan Kesehatan } \\
\text { Mata Pada Anak } \\
\text { Usia 10-12 Tahun. } \\
\text { Tahun Publikasi : } \\
\text { Tahun 2018 }\end{array}$ & $\begin{array}{l}\text { Menggunakan metode } \\
\text { deskriptif kuantitatif. } \\
\text { Populasi : } \\
\text { Siswa SD Negeri } \mathbf{1 0} \\
\text { Salatiga }\end{array}$ & $\begin{array}{l}\text { 1. Responden yang menggunakan gadget dalam } \\
\text { waktu 2-3 jam/hari sebanyak } 45 \text { orang }(66,2 \%) \text {. } \\
\text { Sebanyak } 17 \text { responden }(25.0 \%) \text {. } \\
\text { 2. Responden yang menggunakan posisi duduk } \\
\text { tegaksaat menggunakan gadget sebanyak } 37 \text { orang } \\
(54,4 \%) \text {. Sebanyak } 29 \text { responden } \\
(42,6 \%) \text { menggunakan gadget pada posisi tiduran. } \\
\text { 3. Responden yang tidak pernah menggunakan } \\
\text { gadget ketika cahaya redup sebanyak 35 orang } \\
\text { (51,5\%). Sebanyak 16 orang (23,5\%) } \\
\text { menyatakan sering menggunakan gadget ketika } \\
\text { cahaya redup. }\end{array}$ \\
\hline
\end{tabular}


4. Responden dalam penelitian ini menyatakan menggunakan gadget ketika ada cahaya sebanyak 34 orang $(50 \%)$. Sebanyak 24 orang $(35,3 \%)$ menyatakan kadang-kadang menggunakan gadget ketika tidak ada cahaya.

5. Kondisi kesehatan mata responden dalam penelitian ini dalam keadaannormal sebanyak 54orang $(79,4 \%)$

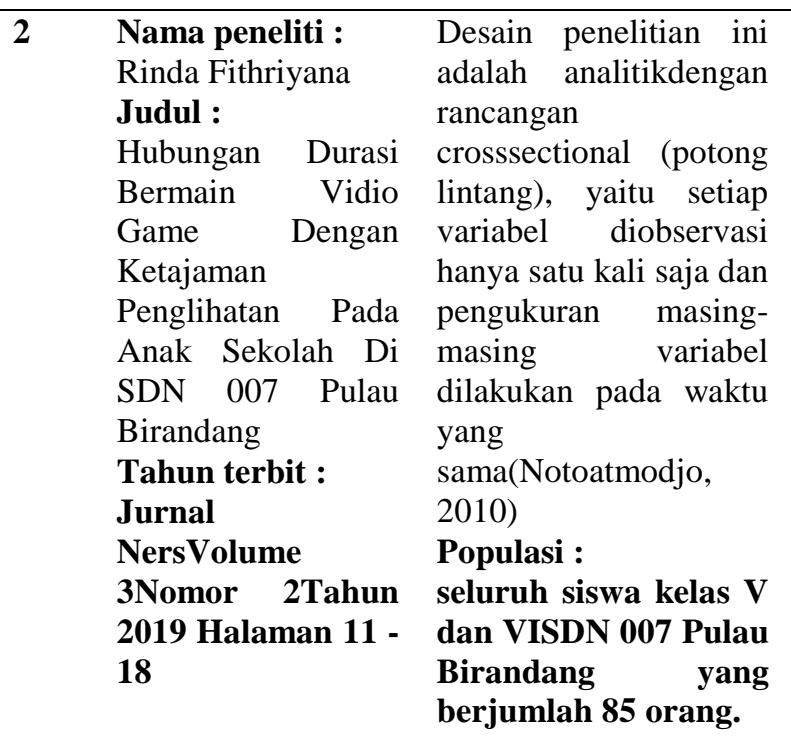

1. Distribusi Frekuensi Karakteristik Resonden Berdasarkan Umur : 11 tahun sebanyak 31 orang $(36,5 \%), 12$ tahun sebanyak 48 orang $(56,5 \%), 13$ tahun sebanyak 6 orang $(7,0 \%)$. sebagian besar responden berada dalam kategori umur 12tahunyaitu sebanyak 48 orang $(56,5 \%)$.

2. Distribusi Frekuensi Durasi Bermain Vidio Games : < 2 jam/hari sebanyak 34 orang $(40,0 \%)$, >2 jam/hari sebanyak 51 orang $(60,0 \%)$. sebagian besar responden bermain video games $>2$ jam/hari yaitu sebanyak 51 orang $(60 \%)$.

3. Distribusi Frekuensi Ketajaman Penglihatan : Normal sebanyak 41 orang $(48,2 \%)$, Tidak Normal sebanyak 44 orang $(51,8 \%)$. sebagian besar responden memiliki ketajaman penglihatan tidak normal yaitu sebanyak 44 orang $(51,8 \%)$.

4. Berdasarkan uji statistikdiperoleh nilai $\mathrm{p}$ value $=$ 0,024( $\mathrm{p}<0,05)$, dengan derajat kemaknaan $(\alpha=$ $0,05)$. Ini berarti terdapat hubungan yang signifikan antara durasi bermain video gamesdengan ketajamanpenglihatan pada anak sekolah di SDN 007 Pulau Birandang tahun 2017. Dari hasil penelitian diketahui nilai POR $=3$,0hal ini berarti siswayang durasi bermain video games $>2$ jam/hariberpeluang $3 \mathrm{kali}$ untuk memiliki gangguan ketajaman penglihatan

\begin{tabular}{|c|c|c|c|}
\hline 3 & $\begin{array}{l}\text { Nama Penulis : } \\
\text { Stella,Susanty Dewi } \\
\text { Winata,Wiwi } \\
\text { Kertadjaya } \\
\text { Judul : } \\
\text { Gambaran Angka } \\
\text { Kejadian Kelainan } \\
\text { Refraksi Pada } \\
\text { Mahasiswa } \\
\text { Fakultas } \\
\text { Kedokteran } \\
\text { Universitas Kristen } \\
\text { Krida Wacana 2013 } \\
\text { Sehubungan dengan } \\
\text { Aktivitas Melihat } \\
\text { Gadget. } \\
\text { Tahun Terbit : } \\
\text { Tahun 2013 }\end{array}$ & 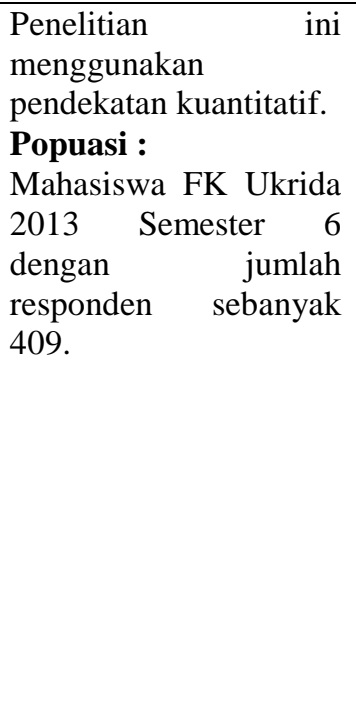 & $\begin{array}{l}\text { 1. Responde ndalam penelitian ini terdiri dari } \\
\text { perempuan yakni sebesar 57orang }(54 \%) \\
\text { sedangkan responden berjenis kelamin laki-laki } \\
\text { adalah } 49 \text { orang }(46 \%) \text {. } \\
\text { 2. responden yang memiliki kelainan refraksi lebih } \\
\text { banyak yaitu } 65 \text { orang }(61,3 \%) \text { dari yang tidak } \\
\text { memiliki kelainan refraksi } 41 \text { orang }(38,7 \%) \text {. } \\
\text { 3. keluhan yang ditemukan paling banyak adalah } \\
\text { keluhan bahwa mata gatal sebanyak } 25 \text { responden } \\
\text { (12,3\%) dan mata lelah sebanyak } 25 \\
\text { responden }(12,3 \%) \text {. } \\
\text { 4. Pemakaian gadget paling banyak ada pada angka } 4- \\
6 \text { jam perharinya, yaitu sebanyak } 54 \text { orang }(50,9 \%) \\
\text { sedangan yang paling sedikit adalah dibawah dua } \\
\text { jam per harinya }(3,8 \%) \text {. }\end{array}$ \\
\hline 4 & $\begin{array}{ll}\text { Nama Penulis : } & \\
\text { Juschella } & \mathrm{J} . \\
\text { Sumakul,Sylvia } & \mathrm{R} . \\
\text { Marunduh,Diana } & \mathrm{V} .\end{array}$ & $\begin{array}{l}\text { Jenis penelitian ini } \\
\text { ialah kuantitatif dan } \\
\text { deskriptifanalitikdenga } \\
\mathrm{n} \quad \text { desain potong }\end{array}$ & $\begin{array}{l}\text { 1. sebagian besar responden telah menggunakan } \\
\text { gadget lebih dari } 3 \text { tahun sebanyak } 119 \text { siswa } \\
(65 \%) \text { dan responden yang menggunakan gadget } \\
\text { kurang dari } 3 \text { tahun sebanyak } 65 \text { siswa }(35 \%) \text {. }\end{array}$ \\
\hline
\end{tabular}




$\begin{array}{ll}\text { D. Doda } & \text { lintang. } \\ \text { Judul : } & \text { Populasi : } \\ \text { Hubungan } & 184 \text { siswa }\end{array}$

Penggunaan Gadget

dan Gangguan

Visus pada

SiswaSMANegeri 1

Kawangkoan

Tahun Terbit :

Tahun 2019
2. seba-gian besar responden menggunakan gadgetdengan durasi lebih dari 4 jam/hari yaitu133 siswa $(72 \%)$ dan responden yang menggunakan gadgetdengan durasi kurang dari 4 jam/harisebanyak 51 siswa (28\%).

3. sebagian besar responden yang menggunakan gadget de-ngan jarak kurang dari $30 \mathrm{~cm}$ yaitu98 siswa $(53 \%)$ dan responden yang menggu-nakan gadgetdengan jarak lebih dari $30 \mathrm{~cm}$ yaotu86 siswa (47\%).

4. sebagian besar responden yang menggunakan gadgetde-ngan posisi tidur/rebahan yaitu 126 siswa (68\%) dan responden yang menggunakan gadgetdengan posisi duduk sebanyak 58 siswa $(32 \%)$.

5. sebagian besar responden memiliki visus normal sebanyak 113 siswa (61\%) dan responden yang memiliki gangguan visus sebanyak 71 siswa (39\%). Sebagian besar responden yang memiliki gangguan visus ialah siswa perempuan dengan jumlah sebanyak 50 responden.

6. hubungan antara lama penggunaan gadget dan gangguan visusyang mendapatkan nilai $\mathrm{p}=0,012$

7. hubungan antara durasi penggunaan gadget dengan gangguan visusyang mendapatkan nilai $\mathrm{p}=0,028$

8. hubungan jarak penggunaan gadget dengan gangguan visus0,008 yang mendapatkan nilai $\mathrm{p}=0,008$

9. hubungan antaraposisi penggunaan gadget dengan gangguan visusyang mendapatkan nilai $\mathrm{p}=0,329$.

\begin{tabular}{|c|c|c|}
\hline 5 & \begin{tabular}{l}
\multicolumn{2}{l}{ Nama penulis : } \\
Nyoman Angga \\
Santosa \\
, Luh Putu Ratna \\
Sundari \\
Judul : \\
Hubungan \\
Durasi Antara \\
Game Bermain \\
Dengan Gangguan \\
Tajam \\
Penglihatan Pada \\
Anak Sekolah \\
Menengah Pertama \\
(SMP) Di Kota \\
Denpasar \\
Tahun Terbit : \\
Tahun 2018
\end{tabular} & $\begin{array}{l}\text { Penelitian ini adalah } \\
\text { observasional analitik } \\
\text { cross-sectional. } \\
\text { Populasi : } \\
\text { Populasi penelitian } \\
\text { merupakan } \\
\text { anak sekolah } \\
\text { menengah pertama } \\
\text { (SMP) di Denpasar } \\
\text { yang memiliki } \\
\text { kebiasaan bermain } \\
\text { game online }\end{array}$ \\
\hline
\end{tabular}

1. Didapatkan jumlah responden laki-laki56 orang $(90,3 \%)$ dan 6 orang $(9,7 \%)$ responden perempuan, usia mayoritas responden adalah 13 tahun $(58,1 \%)$, sedangkan yang paling rendah adalah 15 tahun $(9,7 \%)$. Rerata usiaresponden yaitu $13,52 \pm 0,67$ tahun.

2. Didapatkan sejumlah 28 responden $(45,2 \%)$ bermain selama 1-3 jam, 20 responden $(32,3 \%)$ bermain selama 3-5 jam dan 14 responden $(22,5 \%)$ bermain selama 5 jam.

3. sebanyak41 orang $(66,1 \%)$ mengalami penurunan visus; dengan rincian sebanyak 11 orang $(39,3 \%)$ dengan jumlah durasi bermain game onlinetanpa jeda per hari selama 1-3 jam; 16 orang $(80,0 \%)$ yang bermain selama 3-5 jam; dan 14 orang $(100,0 \%)$ yang bermain game onlineselama >5 jam.

4. Diantara28 siswa yang bermain 1-3 jam per hari, penurunan visus OD dan dan OS berturut -turut yaitu 9 siswa $(32,1 \%)$ dan 7 siswa $(25,0 \%)$. Sejumlah 20 siswa dengan durasi bermain game online tanpa jeda selama 3-5 jam per hari, didapatkan sebanyak 13 siswa diantaranya $(65,0 \%)$ dengan visus OD menurun dan 12 siswa $(60,0 \%)$ dengan visus OS menurun. Sedangkan dari14 siswa yang bermain game onlinetanpa jeda $>5$ jam per hari, tidak didapatkan siswadengan visus OD 
normal dan sebanyak 12 siswadiantaranya( $85,7 \%)$ dengan visus OS menurun

5. sebanyak 36 siswa $(58,1 \%)$ mengalami penurunan visus OD dan 31 siswa $(50,0 \%)$ mengalami penurunan visus OS dari total responden.Analisis bivariat menggunakan uji Chi-square menunjukkan hubungan yang signifikan dengan nilai $\mathrm{P}$ sebesar $0,001(\mathrm{P}<0,05)$

Berdasarkan hasil penelitian dari berbagai jurnal didapatkan kesimpulan bahwa terdapat Hubungan Penggunaan Komputer dan Gadget terhadap Penurunan Tajam Penglihatan. Didapatkan hasil bahwa Jika terus menerus menatap layar pada gadget dalam waktu yang lama, hal itu dapat menyebabkan masalah pada penurunan ketajaman penglihatan. Gangguan ketajaman penglihatan yang terjadi pada anak usia sekolah menjadi masalah kesehatan yang perlu diperhatikan.

Menurut Horrigan (2002), intensitas tediri dari dua aspek,yakni :

\section{A. Aspek Frekuensi}

Merujuk pada tingkatan atau seberapa sering subyek bermain gadget.Intensitas bermain gadget dengan frekuensi tinggi adalah lebih dari 10 kali setiap harinya, intensitas frekuensi bermain gadget dengan intensitas sedang adalah antara 3-10 kali setiap harinya, dan intensitas bermain gadget dengan frekuensi rendah adalah kurang dari 3 kali setiap harinya.

\section{B. Lama Mengakses.}

Aspek ini mempunyai arti penting karena berapa lama waktu yang digunakan untuk bermain gadget.Durasi tinggi dalam bermain gadgetjika dalam sehari lebih dari 10 jam, durasi sedang jika dalam sehari bermaingadgetantara 2-10 jam, durasi rendah jika dalam bermain gadgetkurang dari 2 jam

Berdasarkan hasil literatur-literatur diatas didapatkan bahwa :

- Terdapat hubungan antara durasi penggunaan komputer dan gadget dengan ketajaman penglihatan.

- Penelitian pada anak SMP dengan rentan usia 13-15 tahun didapatkan kelainan refraksi lebih banyak didapatkan pada jenis kelamin perempuan. Hal tersebut dapat dijelaskan dari fakta bahwa laki-laki lebih banyak menghabiskan waktunya berada di luar ruangan sedangkan perem-puan cenderung lebih banyak melakukan aktivitas di dalam ruangan seperti membaca, menulis, menjahit, merajut dan melakukan aktivitas melihat dekat lainnya.

- Penggunaan komputer tanpa jeda dapat menimbulkan Computer Vision Syndrome(CVS) yang dapat berpengaruh pada nilai tajam penglihatan.

- VISION 2020, suatu program kerjasama antara International Agency for the Prevention of Blindness(IAPB) dan WHO, menyatakan bahwa pada tahun 2009 diperkirakan 153 juta penduduk dunia mengalami gangguan tajam penglihatan akibat kelainan refraksi yang tidak terkoreksi.Sekitar12 juta diantaranya adalah 
JURNAL SEHAT MASADA VOLUME XVI

anak-anak usia 5-15 tahun menderita gangguan tajam penglihatan karena miopia, hipermetropia, dan astigmatisme.

- Dampak menurut Departemen Kesehatan(DepKes), kelelahan matadapat mengakibatkaniritasisepertimata berair, kelopak mata berwarna merah, penglihatan rangkap, sakit kepala, berkurangnya dayaakomodasi, dan ketajaman mata menurun

- Menurut Rifhani (2010), Kebiasaan bermain game online lebih dari 2 jam perharisecara otomatis akan menyebabkan pengguna berlama-lama melakukan kontak mata langsung dengan layar komputer, tampilan layar monitor yang terlalu terang dengan warna yang panas seperti warna merah, kuning, ungu, oranye akan lebih mempercepat kelelahan pada mata. Pemakaian layar monitor yang tidak ergonomis dapat menyebabkan keluhan pada mata.

- Intensitas menatap layar gadget, pencahayaan, posisi duduk ada hubungannya dengan penurunan tajam penglihatan.

\section{KESIMPULAN}

- Responden yang durasi penggunaan komputer dan gadget nya > 2 jam menyebabkan gangguan penglihatan disebabkan karena kelelahan mata akibat terlalu lama di depan komputer dan gelombang elektromagnetik yang dihasilkan monitor komputer dapat mengganggu kesehatan mata.
NOMOR 1 Januari 2022

ISSN : 1979-2344

- Penurunan ketajaman penglihatan tersebut tergantung dari lamanya durasi paparan dengan layar monitor sehingga pada saat bermain video game dianjurkan untuk tidak melebihi 2 jam setiap harinya

- Penelitian Bhanderi et al23 melaporkan bahwa angka kejadian CVS lebih tinggi pada pengguna perangkat elektronik yang bekerja secara terus-menerus dalam sehari. Seorang individu yang bekerja di depan layar/monitor selama lebih dari atau sama dengan 4 jam secara terus-menerus berisiko dua puluh enam kali lipat menderita CVS (Computer vision syndrome) dibandingkan dengan bekerja di depan komputer selama kurang dari 4 jam secara terus-menerus.

\section{DAFTAR PUSTAKA}

W. E. (2015). Pengarus Penggunaan Gadget Terhadap Penurunan Tajam Penglihatan pada anak Usia Sekolah (6-12 Tahun) di SD Muhammadiyah 2 Pontianak Selatan. Jurlan Prones.
Andiawan, A. (2019). Hubungan Lama Pemakaian Komputer Dengan Penurunan Ketajaman Penglihatan Pada Siswa Teknik Informatika Komputer Di Smkn 3 Mataram. Mataram.

Fithiraya, R. (2019). Hubungan Durasi Bermain Video Game dengan ketajaman Penglihatan pada Anak Sekolah di SDN 007 Pulau Birandang. Jurnal Ners.

Foraldy, T. (2019). Memahami Proses Pemeriksaan Ketajaman Visus (Penglihatan) Mata. hello sehat.

Ilyas, S. (2008). Buku Ilmu Penyakit MataEedisi Kelima . Jakarta: FKUI.

Ilyas, S. (2019). Buku Ilmu Penyakit Mata. Jakarta: Dede Pustaka. 
Juschella J. Sumakul, 1. R. (2019). Hubungan Penggunaan Gawai dan Gangguan Visus pada SiswaSMANegeri 1 Kawangkoan. ebiomedik.

Maya Syulfharita Pertiwi, T. P. (2018). Gambaran Perilaku Penggunaan Gawai dan Kesehatan Mata Pada Anak Usia 10-12 Tahun. Keperawatan Muhammadiyah.
Mumtaza, H. I. (2019). Perbedaan Tajam Penglihatan Berdasarkan Pola Penggunaan Gadget pada Sekolah Menengah Pertama Negeri 2 Jember . Universitas Jember.

Murtopo, I. (2005). Pengarus Radiasi Layar Komputer Terhadap Kemampuan Daya Akomodasi Mata Mahasiswa. Publikasi Ilmiah. 